\title{
Conservation Of Javanese Cultural Haritage As Strategy To Strengthen The Nation Characterand Maintain The Local Wisdom (Case Study Lagu Dolanan Anak)
}

\author{
Muhammad Abdullah*, Merya Anggraeni \\ Indonesia Department, Faculty of Humanities, Diponegoro University, Semarang 50275, Indonesia.
}

\begin{abstract}
In the context of today's global society, the presence and redisclosure of lagu dolanan text contents will be able to provide an alternative new colour to public education which is beginning to be torn apart by modern culture, especially, character-based education. One of Javanese cultural heritage is the existence of lagu dolanan anak which are scattered in various coastal areas of Central Java. Among the lagu dolanan anak are Ilir-ilir, Sluku-sluku Banthok, Gundhul-gundhul Pacul, Plok Ame-ame, Lela Ledhung, Cublak-cublak Suweng, Padang Bulan, and etc. The songs reflect the wealth of local wisdom which is full of moral values, spiritual values, and philosophical values of Javanese society. Basically, the noble values which are contained in lagu dolanan anak can be used as a vehicle and educational media of modern society who had not recognized their own culture, and it can be used to develop patterns of character-based education and the development of a dignified civilization. The aim of this research is to save and preserve lagu dolanan anak as the cultural heritage in the coastal society which are scattered in various rural areas.
\end{abstract}

Keywords: Lagu Dolanan Anak; Local wisdom; Character; Oral Tradition.

\section{Introduction}

According to Endraswara, oral folklore is one aspect of folklore which is still alive but has lack of attention from the supporting community [1]. One of Javanese oral folklore which is still alive is lagu dolanan anak. In the context of today's global society, the presence and redisclosure of lagu dolanan text contents will be able to provide an alternative new colour to public education which is beginning to be torn apart by modern culture, especially, characterbased education [1]. One of Javanese cultural heritage is the existence of lagu dolanan anak which are scattered in various coastal areas of Central Java. Among the lagu dolanan anak are Ilir-ilir, Sluku-sluku Banthok, Gundhul-gundhul Pacul, Plok Ame-ame, Lela Ledhung,

*Corresponding author : abdullahabah47@gmail.com 
Cublak-cublak Suweng, Padang Bulan, and etc. Why oral tradition (oral folklore) of lagu dolanan anak must be preserved? It is because the songs reflect the wealth of local wisdom which is full of moral values, spiritual values, and philosophical values of Javanese society.

Basically, the noble values which are contained in lagu dolanan anak can be used as a vehicle and educational media of modern society who had not recognized their own culture, and it can be used to develop patterns of character-based education and the development of a dignified civilization. Today, the great works of the inheritance begin and have been abandoned by their owners. Because of that background, it is necessary to conduct preservation, conservation, and real revitalization towards the text of lagu dolanan anak which has high cultural values.

There are three steps which can be conducted for the effort. First, identify and inventory the texts of existing lagu dolanan anak, then describe each text of lagu dolanan anak which are contained in various regions in Central Java. Second is the re-actualization of lagu dolanan anak texts in the form of lagu dolanan anak festival. Third, hold a recording of lagu dolanan anak text in the form of audio and video clip. This study was conducted with the following purposes. (1) The specific purpose to be achieved from this research is to save and preserve the old cultural heritage of the philosophical values contained in the texts of lagu dolanan anak. (2) The second specific purpose is to save the texts of lagu dolanan anak as a valuable local wisdom asset. (3) The third purpose is reflecting philosophical values to strengthen character education for the young generation.

Talking about literary function in society, we often cite the opinions of Renne Wellek and Austin Waren in their book entitled The Theory of Literature, that the function of literature is "dulce et utile", fun and useful [1]. In this understanding, literary works are considered to have strategic significance for the reader, both of the esoteric and exoteric aspects. Therefore, in this context, a good literary work is a work which can build souls, give a positive value to the reader in order to be "interesting, fun, and entertaining" and can be useful, beneficial, and educational" for the readers. According to Ahmad Tohari, good literature is a literary work which can move the heart, touch the feeling of the soul, and influence the readers' worldview [2].

In turn, the existence of literary work as the product of the past culture is not only useful individually and only limited to the reader, but also can be massively useful for the reader's society. Indeed, it may be that such great literary works will be able to change the worldview of a reader or a country. In the context of today's global society, the presence and redisclosure of these work contents can provide an alternative new color to public education which is beginning to be torn apart by modern culture. One of cultural heritage is the existence of lagu dolanan anak which are scattered in various regions in Java [2].

\section{Method}

To support the input of data information, this research will be conducted by applying the following method. First, folklore research method as oral tradition research method which is inventory and text identification method [3]; second, the literature review method; and third, field research method by text recording and the implementation of lagu dolanan anak festival [3]. In this case, it is necessary to conduct focus group discussion (FGD) and text reproduction training. In practice, the description of oral literature method can gradually follow the following steps [3]. (a) Inventory and identification of lagu dolanan anak scattered in Javanese society which most of them are not appreciated by the modern society; (b)Conducting text identification and description: recording and selecting the physical condition of the text by interview approach; (c)Classifying the text: Choosing the most 
important texts to get the best texts; (d) Text compilation method: collecting the best oral text which will be the selected text [3].

\section{Results and Discussion}

Actually, the main reason and urgency of this study is the important of preserving the values contained in lagu dolanan anak as the past cultural heritage in the coastal region. If this oral tradition is able to be preserved and saved by revitalizing the text, then the opportunity of the younger generation, especially academics, to conduct research folklore is more opened. Thus, this study also has the academic urgency to advance nation science and technology to meet the prospective future of the nation constructively. In the other words, this study has a sociocultural urgency for saving the cultural haritage and the academic urgency for the advancement of science [3].

In particular, this research will be part of the progress in science and technology, especially in the field of folklore and tourism research. This is based on the fact that by conducting this research, there are three new findings, which are: (1) the resurrection of various types of lagu dolanan anak from extinction; (2) the re-establishment of oral culture laboratories, which are some places of rewriting lagu dolanan anak with the spiritual wealth of the nation; (3) the results of both research activities will functionally become coastal assets for strengthening the religious tourism village in coastal areas.

One of the cultural heritage works of coastal society is the pesantren literary work. Pesantren literary work is a collection of sastra kitab works (religious literature), oral literary works, and syi'ir literary works which was born and developed in the pesantren environment, and relates to the problem concerning the dogmatic-ritual teachings as well as rationalspiritual teachings. The characteristics of pesantren literary works are: (1) pesantren literature is usually written in Arabic and uses Arabic language, (2) sometimes, pesantren literature uses new Javanese language with Arabic-pegon writing, (3) it was born and developed in the early 19th century (4) pesantren literature is in the form of oral and written traditions, containing moral teachings, fiqih, monotheism, tasawwuf, theology, syi'ir works, nasyid, and etc, (5) sometimes, pesantren literature is read in halaqah ilmiah, certain ritual ceremonies, and sometimes performed as performing art, and (6) pesantren literature is also slightly influenced by Middle Eastern literature, Arabic literature or Persian literature [3].

\section{Conclusion}

According to the explanation above, the research result can be concluded that lagu dolanan anak Jawa can reveal values of the past which can give moral messages for strengthening the nation children's character by revitalizing the function of literary works and actualizing old text in the context of modern society. Therefore, we can know how far the role of coastal literary works as the products of the past can increase the quality of community enpowerment. 


\section{References}

1. Liaw Yock Fang. Kesusastraan Melaytu Klasik. Kuala Lumpur : Pustaka Nasional. (1978)

2. Indraswara, Suwardi. Foklor Jawa. Jogjakarta : Bentang.( 2012) 2014. Hermeneutika, Estetika, dan Freligiusitas. Jogjakarta : Maha Karya.

3. Wahid, Abdurrahman. "Nahdlatul Ulama dan Islam di Indonesia Dewasa ini" dalam Tradisi dan Kebangkitan Islam di Asia Tenggara (Taufik Abdullah, Ed). Jakarta : LP3ES. (1989)

4. Wellek, Rene and Austin Waren. Theory of Literature. (Terjemahan Achadiati Ikram). Jakarta : Gramedia. Teeuw, A. 2005. Sastra dan Ilmu Sastra. Jakarta : Gramedia. Teeuw, A. 1994. Antara Kelisanan dan Keberaksaraan. Jakarta : Gramedia. (1970)

5. Zoetmulder. Manunggaling Kawula Gusti. Jakartra : Gramedia. (1997)

6. Simuh., Mkistik Islam Kejawen Raden Ronggo warsito. Jakarta : UI Press. (1998)

7. Kratz, E.U. "The Editing of malay Manuscripts and Textual Criticism" dalam BKI 137

8. Dananjaya, James. Folklor Indonesia. Jakarta : Gramedia. (1985)

9. Djamaris, Edwar. Metode Penelitian Filologi. Jakarta : C.V. Manasco. (2004)

10. Baried, Baroroh. 1995. Pengantar Teori Filologi. Jakarta : Pusat Bahasa. 1977. Kamus Istilah Filologi. Yogjakarta : UGM.

Basuki, Anhari. 2004. Metode Penelkitiabn Sastra Lama. Semarang: FS Undip.

11. Azra, Azumardy. "Islam dan interaksi budaya Kalimantan" dalam Festival Istiqlal Jakarta. (2005)

12. Abdullah, Muhammad. Khazanah Sastra Pesisir. Semarang : Undip Press. 2009. Dekonstruksi Sastra Pesantren. Semarang :

Fasindo. (2008)

13. Basuki, Anhari. 2004. Pengantar Filologi. Semarang : Fasindo.

14. Thohir, Mudjahkirin. 1997. Inventarisasi Sastra Pesangtren. Semarang : Undip. 